\title{
Theory versus Pragmatism: Quest of Achieving Academic Objectives in Kenyan Universities
}

\author{
David Sande Ouma ${ }^{1}$ \\ ${ }^{1}$ Sociologist and Dean of Studies, FPFK Goodhope School, Nairobi-Kenya \\ Correspondence: David Sande Ouma, FPFK Goodhope School, Nairobi-Kenya. \\ Email: sandedavid64@gmail.com
}

Doi: $10.23918 /$ ijsses.v8i1p18

\begin{abstract}
University is the highest epitome of attaining knowledge and education to an individual. In Kenya, the universities have been viewed as being pivotal in helping accomplish the vision 2030 and drive its development agendas. Unfortunately, the country's goals are dwindled by a myriad of challenges, particularly from the incompetent university graduates. It is on this premise that this research review helps in articulating several thematic issues that include: one, the number of enrolled students vis-à-vis the available infrastructure and lecturers; two, the type of teaching methodology that is employed; three, the quality of university lecturers' competencies; four, correlation between the university curriculum and employment demands; and five, influence of university infrastructure towards the quality of lectures delivered. This paper opines that: students' enrollment to universities should be regulated to match the existing infrastructures. Secondly, lecturers ought to change with time in their teaching methods, allow students to do more library research, and write their notes. Thirdly, it is imperative for a review of university curriculum, to reduce theory lectures and enhance pragmatism of different ideas. Fourth, universities should improve their infrastructures to have a conducive learning environment for research and quality scholarship. The paper thus concludes that, if the above control mechanisms are incorporated to the universities, the issue of the deteriorating quality of university graduates will be a thing of the past.
\end{abstract}

Keywords: Graduate, University, Lecture, Lecturer, Pragmatism, Quality

\section{Introduction}

Since the attainment of independence, Kenya government established different development strategies, with the aim of empowering its populace and improving economy at large (Zeleza, 1991; Leys, 1979). It did so through focus on education sector that produced both skilled and semi-skilled labour force in the country (Zeleza, 1991; Leys, 1979). In doing so, the government came up with several taskforces whose recommendations were to offer a way forward on education implementation. For instance, during President Jomo Kenyatta's tenure, he formed the Ominde Commission whose report in 1964 recommended an education system that appreciated national unity, ethos, and creation of sufficient human capital for national development (Eshiwani, 1993). Another commission, that was referred to as Koech Commission, which was formed by President Daniel Arap Moi in 2000, mainly recommended avenues of

Received: December 12, 2020

Accepted: February 25, 2021

Ouma, D.S. (2021). Theory versus Pragmatism: Quest of Achieving Academic Objectives in Kenyan Universities. International Journal of Social Sciences \& Educational Studies, 8(1), 18-36. 
improving education to foster national integration, and increase industrial and technological advances (Rono, 2002). These two sampled commission's recommendations can be summed to; the quality of education is imperative as it is directly congruent to the quality of its graduates.In recent times, there has been a mutating discourse, critiquing the quality of education that is being offered in our Kenyan universities (Kamande, 2019; Munene, 2016a; Njeri, 2019; Ouma, 2016; Oduor, 2017; Munene, 2016b). This has had a negative connotation and perception to most employers, who in turn, have been hesitant to hire Kenyan university graduates (Oduor, 2017). This challenge has made the country to have high statistics of its university graduates being unemployed and 'tarmacking' (Oduor, 2017). As Kamande (2019) posits:

In recent figures released by the United Nations Development Programme (UNDP), Kenya is ranked as having the highest unemployment rate in East Africa. With so many students graduating each year from institutions of higher learning, a degree is no longer a guarantee of employment.

This is a menace that has not only been encapsulated in the country, as other countries in the region have also witnessed the same. Their challenges have ranged from increased enrollments, lack of research and innovation, poor teaching methodologies, and lack of finances (Mgaiwa, 2018; Alemiga \& Kibukamukose, 2019). For instance, in Uganda, there have been a continued focus of increased students' enrollment by private university managements, with a view of sustaining them (Alemiga \& Kibukamukose, 2019). Key practices for quality education delivered such as review of their curriculum, employing lecturers on merit, observing fairness and merit in promotions, and giving academic staffs favourable and stable contracts that reduce regular turnover has been given a back foot (Alemiga \& Kibukamukose, 2019). This has resulted into the release of graduands into the job market, who are semi-skilled, also referred to as 'half baked' graduates (Ssekamwa, 2007). There has also been an emerging discourse of which courses are critical for nations' development. From a broader perspective, the courses are classified into life sciences, technology, humanities, and social sciences (Daily Monitor, 2016). The gist of the argument has been, a majority of student's flock into the humanities and social sciences, as they handle little experimentations and are comparatively cheaper (Cambon, 2019). This has not augured well to some people, considering that the contemporary society centers around information and communication technology (ICT), innovation, hands on projects such as engineering; thus, the establishment of polytechnics and vocational training centers (Daily Monitor, 2016). In other words, it is held that in the current global status, theoretical knowledge of an expert does not supersede one's practical abilities, in steering change in all spheres of human life, be it political, socio-economical and technology. It is on this background that the paper aims to answer the following questions:

1. Do the teaching methodologies and lecturers employed in the universities have an influence on the quality of graduates produced?

2. What is the correlation between the university curriculum and the employer's requirements?

3. What is the impact of the existing student enrollments in universities vis-à-vis the available infrastructure and lecturers? 


\section{Scholarly Perspectives on Education}

The concept of education and its outcome is one that has been discussed variously by scholars. One of the perspectives is Bloom's Taxonomy that was propounded by Benjamin Bloom in 1956 (Heick, 2018). He endeavored to outline a systematic if not scientific method of carrying out education process without void of confusion; or bombarding learners with much information at the same time (Heick, 2018). In his discourse, he attempted to bring out four critical aspects of learning, which included: knowledge, skill, capacity and will, which if incorporated correctly, enhances the attainment of educational objectives (Köksal \& Ulum, 2018). In essence, knowledge is entailed in the curriculum content that is passed to the learners; skill majorly targets the teachers who are custodians of the curriculum content, and the methods they use in teaching and nurturing the same on their learners; capacity involves looking at the psychosocial and physical ability of both the learner and teacher; and will that entail the attitude and drive of the learner in grasping what is taught in the curriculum (Dong, 2014).

According to Blooms taxonomy perspective, he dissected the process of educating a learner into two broad categories, which included: low order thinking skills, and high order thinking skills (Adams, 2015). The low order thinking skills can be termed as the firsthand information given to the learner; mostly for easy retrieval and academic survival (Adams, 2015). These skills involve aspects such as remembering and understanding. Remembering entails memorization of a given content, and understanding entails making sense of what you have learnt (Adams, 2015). Students that possess low order thinking skills are referred to as surface learners, who only reproduce what they have learnt for examination success, and forget about them (Dong, 2014). The high order thinking skills, are the ones that university graduates must possess as the institutions are considered as an epitome of academic knowledge. The skills entail applying, evaluating, creating and analyzing the information that is given to them (Köksal \& Ulum, 2018). Students at the universities that possess these higher thinking skills are referred to as deep or strategic learners. Generally, Bloom was of the view that, the process of teaching should be systematic, and learners assessed using the right process to ensure the objectives are met (Athanassiou, McNett \& Harvey, 2003). In addition, it is through the possession of higher thinking skills that university graduates can demonstrate their pragmatic skills to challenges brought to them (Adams, 2015).

Samuel Bowles and Hebert Gintis propounded the conflict perspective of education in society (Gottesman, 2013). According to their discourse, the perception of equity in our contemporary society is utopia, as it is characterized by competition and individualism (Gottesman, 2013). To them, most of the societies have assimilated the concept and practice of capitalism, where the bourgeoisies control capital influence of education, which is the only hope towards upward social mobility of many poor populace (Knopp, 2010). Education is viewed as a production room for workforce rather than encourage innovation, selfproprietors; to benefit the bourgeoisies (Gottesman, 2013). This has been facilitated by teaching questionable curriculum that is so rigid and does not allow flexibility to the recipients thus maintaining the wider disparity of the rich and the poor (Swartz, 2003). That is the reason the children from rich families will always get higher academic skills and higher skilled jobs; while those from the poor backgrounds possess low skills, and thus given low cadre jobs (Knopp, 2010). This is a position that is supported by the argument of Karl Marx on class conflict perspective (Gottesman, 2013). This status quo on education access goes against the position of Emilé Durkheim whose thoughts were that: education 
ought to be owned by the society at large, be a mirror of societal behavior, and be social in function (Prus, 2011). In a nutshell, the poor in society will always remain captives of the rich persons.

John Dewey was also pivotal in elucidating the aspects of pragmatism in education for the betterment of the learner and society at large (Pavlis \& Gkiosos, 2017). According to him, having the traditional form of learning where teachers solely control education and information, makes the learners to be passive, and ones that cannot be resourceful to the society (Pavlis \& Gkiosos, 2017). This is because learners will rely heavily on the tutors to be spoon fed, and not be initiative. In doing so, Dewey appreciated the critical relationship that the schools, students, and society ought to have (Dewey, 2018). From a sociological perspective, schools play a critical role in socializing the learner to societal expectations and ways of life. At the university level, students will be trained on critical skills such as problem solving, critical thinking, interpersonal skills and so forth, all which are beneficial to the contemporary society that has a myriad of challenges to solve. Dewey thus opined that, it is imperative for schools to adopt experiential learning and practical sessions to fascinate learning process and allow learners to have real life experience (Dewey, 2018). On this premise, Dewey (2018) propounded that:

Dewey's "Reflex Arc" paper applied functionalism to education. "Reflex" argued that human experience is not a disjointed sequence of fits and starts, but a developing circuit of activities. Learning deserves to be framed in this way: as a cumulative, progressive process where inquirers move from the dissatisfying phase of doubt toward another marked by the satisfying resolution of a problem. "Reflex Arc" also shows that the subject of a stimulus (e.g., the pupil) is not a passive recipient of, say, a sensation but an agent who takes it amidst other ongoing activities in a larger environmental field.

In summary, therefore, the works of Benjamin Bloom, Samuel Bowles and Herbert Gintis, John Dewey and Emilé Durkheim agreed that education is an important possession to an individual and society at large. To be of great help, it is imperative for education to be owned by the society for sustainability purposes, and the people association with the entire process. The process of education is one that must be carried out in a clearly laid out curriculum, which stipulates the methodology of its dissemination, resources to be used, timeframe and the desired outcomes. There has also been a close effort of interrelating education to employment. In essence, education has been a tool that has been used to equip its learners with important skills, that has been used in providing remedies to the contemporary society.

\section{Students Enrollment vis-à-vis Available Infrastructure and Human Labour}

The universities have been centers within the society where its intellectual cream meet to pursue education and impact positively to the society (Odhiambo, 2016). In Kenya, before the millennium, it only had seven public universities that effectively accommodated the low numbers of students that were enrolled in these institutions. In fact, the students were given upkeep money they referred to as 'boom' that could sustain them during their semesters, in terms of meeting their expenses and so forth (Mwangi, 2018). To this era of graduands, after graduation, they secured jobs directly to different government ministries and parastatals; and thus, were held by high esteem in the society (Kamande, 2019). This was the departure point that made the populace to start having a mindset that university credentials are key to getting employment and having a prosperous life (Cambon, 2019). 
Unfortunately, due to the structural adjustment programmes that the government had to put in place to sustain the country's economy, this reduced the funding to universities (Rono, 2002). The introduction of free primary education in 2003 by NARC administration also greatly increased secondary schools enrollment, and further trickled to the university level (Oduor, 2017; Ouma, 2018). This surge of students who qualified to join the universities saw the government in academic year of 2011/2012 introduce double intake (Opata, 2016). In essence, the Kenya Universities and Colleges Central Placement Service (KUCCPS) that is mandated with doing selection of students who scored the national cut off led one government intake, whose student's fees are sponsored by the government (Ouma, 2018). The second mode of admission is Module II programme or private self-sponsored programme (PSSP), where students pay for their fees (Oduor, 2017). This thus led to having regular classes (full time), part time studies, school-based programs, and online distance learning (Oduor, 2017).

Despite of these rising number of student enrollment, the universities infrastructures, and more so, lecture halls, libraries and hostels have not increased, thus leaving students to look for accommodation outside the school compound (Munene, 2016a; Mungai,2019; Cambon, 2019; Njeri, 2019). This status quo thus raises two fundamental questions: one, with the continued rise and desire for higher academic education, where will the students be placed? Secondly, what will be the fate of our university education in the next decade or so? The issue of accessibility and increased enrollments in universities has deviated from the real purpose of the institutions (Mwangi, 2018). For instance, it is not sufficient to be a graduate who cannot offer solutions to different challenges in society. This will signify that we only appear to have institutions of higher learning that are non-beneficial. According to World Bank (2003), as cited in Ngalomba (2020) that elucidated on development of universities in Ethiopia, it held the view that unplanned increase of students was detrimental to declining quality of their graduands. In Kenya, universities have strived to move out of their financial difficulties, by absorbing more students, through established satellite campuses in major towns and cities (Mwangi, 2018; Opata, 2016). The main shortfalls of these satellite campuses are that they lack good environs that offer good ambience for learning; as some are close to pubs and restaurants, in busy streets with a lot of noise pollution and so forth (Opata, 2016; Munene, 2016a). In addition, they lack essential facilities such as equipped library for students to conduct research (Munene, 2016b).

Based on the above challenges, in some of the satellite campuses, they have ended up in the bad books of the commission of university education (CUE) (Mwangi, 2018; Opata, 2016). The CUEs main mandate is to ensure that all the universities in the country offer courses that are accredited by them, together with relevant professional boards, ensure that the curriculum offered is above board and of benefit to the students, ensure the availability of critical aspects such as, adequate lecture halls, professors, libraries, and good environment for learning (Ouma, 2016). For instance, in a random inspection of satellite campuses by CUE across four regions, that is, Nairobi, Western, Nyanza and Rift Valley, it noted that a significant number had not met the required threshold, thus cracked the whip by closing a total of 38 campuses (Opata, 2016). This has been attributed to their questionable enrollment of the students based on the minimum requirements of a $\mathrm{C}+$ (plus) for a secondary school leaver, total lack of libraries, severe shortage of lecturers, the learning facilities are too small to accommodate the students et cetera (Mwangi, 2018). 
Therefore, the continued rise in the hunger of university education in the country must be given the attention it deserves. We need to ponder on the fact that, before the millennium, an undergraduate degree was enough for an individual to secure employment; thus, the increased desire to get them by all mean, be it legally through attending classes or not (Sawahel, 2018). Employers' requirements to a certain level also directly influence the raising numbers of university students, and soon they might settle on a minimum of a master's degree, and if not controlled, that will be the sweet death of the quality of universities post graduate programmes. In other words, the quality of research will be wanting, the level of innovation will decline, and generally the degree certificates will only be papers, analogized as a toothless dog that cannot bite. The question of lecturers executing their responsibilities that entail lecturing, pursuing research, examining students, and providing mentorship to students is a nightmare. In most universities, more so in the public ones, a single class might end up having more than 1000 students, particularly in the so called 'common units' (Munene, 2016a).

This therefore causes lethargy on the lecturers who teach both the undergraduate and postgraduate students, thwarting any efforts of attaining quality scholarship in the institutions (Cambon, 2019). In addition, it is also difficult for lecturers to monitor the progress of their individual students, know those that attend lectures and those that fail to attend; thus, this trigger subjective outcome recipes of students to obtain favourable grades for exchange of cash or even sex (Munene, 2016a). This has in turn led to students from the rich families and professors opting to go abroad to study and teach respectively in prestigious universities, causing a statistical deficit on the side of the later (Njeri, 2019). The consequences of having a shortage of professors in our universities has been triggered by one, 'brain drain' as most of the professors feel they are underpaid and not appreciated well hence leave for greener pastures abroad (Winkler, 1997; VOA, 2009). Secondly, most of the lecturers who possess master's degrees are fascinated by the foreign scholarships to pursue their Doctor of Philosophy degrees abroad (Sawahel, 2018). This lessens the challenge of going through the program in the country that takes a long period of time to pursue due to unavailability of student's supervisors, who are the limited professors (Winkler, 1997). Thirdly, the lack of requisite supplies to advance academic knowledge, that is, through pursuing research has derailed more meaningful innovations (Cambon, 2019; Mwangi, 2018; Nganga, 2020; Mgaiwa, 2018). The university libraries are stocked with outdated reading materials, limited funding to carry out research, and lack of technology to fasten learning through e-learning.

This quagmire has handtied university managements in enforcing their professors to work in their respective institutions on a full-time basis (Winkler, 1997). This has led to a significant number of them to opt working for nongovernmental organizations, government, and even private institutions as consultants, with their remaining time, serving as part time lecturers thus having technical appearance in the institutions (Winkler, 1997; Ouma, 2016). Fourth, is the aspect of quantitative work overload, that puts off lecturers in their quest to deliver quality training to students (ICEF Monitor, 2017). This is exhibited through their enormous duties in their respective departments, pursuing research, presenting papers to different conferences and seminars, publishing scientific journals, teaching, examining, and supervising students (ICEF Monitor, 2017).

In summary, therefore, it is abtly clear as day and night that now, the country is grappling with the constant increase of student enrollments at the university level. This has posed a challenge to the available 
infrastructures due to the massive overflow of students. This has further unearthed the mismanagement of these universities, particularly on how they spend the money they receive. For instance, a lot of cash is spending on payment of salaries and debts as opposed to facilitating initiatives such as development and upgrading of their infrastructures such as lecture halls, libraries, and hostels.

It has also been elucidated that the main objective of having universities has shifted their goal posts of academic excellence to sourcing for money. This has been exhibited by the mushrooming numbers of satellite campuses, whose revenues go back to the main university. In essence, the main universities are starved of the money they could use for development, in the name of establishing satellite campuses. The success of university education cannot be discussed in isolation of the lecturers who are the custodians of the curriculum. If they are not remunerated properly, then the quality of training they offer to students will be below par; with the students suffering in the long run as being 'half baked' graduates, and their services being obsolete to the society. Finally, university student enrollments ought to be strictly regulated, and the commission of university education (CUE) is a sleeping elephant that ought to wake up and do away with this rot exhaustively.

\section{Correlation between University Curriculum and Employers' Requirements}

In any societal setting, socialization is inevitable, and to a certain extend is subject to conflicts due to varying perceptions of ideas. In the ancient times, religion was the sole source of providing knowledge and remedies to the societal grievances faced (Levine, 2018). In the 15th century, during the age of intellectual reawakening, people started to critique religion, as it was based on spiritual feeling and belief and lacked physical practicality (Levine, 2018). This thus introduced the scientific approach of managing the people and their grievances (Levine, 2018). From a broad perspective, the society shapes the content of the curriculum that is taught, to fill the loopholes within the society (Daily Monitor, 2016). That is the reason why we have numerous think tanks across different sectors such as technology, economics, health, education, research and development, citizen service and so forth. The university curriculum thus empowers its students on how to go about providing solutions to the identified challenges (Oduor, 2017). For instance, if it is all about poverty alleviation which has been a chronic grievance to humanity, more so, in developing countries in Africa, Asia and South America, it will enable them to train international development professionals that will formulate a systematic and objective approach, in identifying the households living below the poverty line. This will help in informing policies on how to alleviate them, as they can use the participatory poverty assessment technique to have a one-on-one contact with the people, and do the identification without bias, among many other methods.

In this case therefore, education is used as a change agent of bringing progress from the initial pathetic state of the society. The working framework in unison between education and the society, supports the perspective held by professor Chitere (1994) in his book titled Community Development: Its Conceptions and Practice with Emphasis on Africa, where he argued that real and long-standing changes can only be accomplished when the people are involved and feel part of the drivers of change. This therefore requires the learners to be stimulated by doing practicals and going to the field to have a first-hand experience on how to identify the less fortunate families, learn on how to formulate a work plan, how to solve emerging issues and discrepancies in the field (Chitere, 1994). All these skills and competencies cannot be achieved by only sitting and listening to lectures in a lecture room (Kwarteng \& Ofosu, 2018). In the above reasons, 
therefore, the curriculum must subscribe and be in tandem to the societal needs, failure to which, it will be considered obsolete (Daily Monitor, 2016; Oduor, 2017). In the 21st century, there has been much debate surrounding which courses are considered more important than others (Daily Monitor, 2016). For instance, most campuses have a clear cut of courses that are classified as technology, humanities and social sciences, engineering, agriculture, and life sciences. In most scenarios, engineering and life sciences are given much priority as compared to other courses.

The major argument is that the other courses, more so, humanities and social sciences do tune their students to much theory and memorization as opposed to creativity and innovation (Daily Monitor, 2016). The contemporary society is more of the inner creativity of an individual, and hence has cut a niche to the technological and life sciences. This discourse thus rekindles one pitting natural science versus social sciences, on which one is a science? Scholars such s Auguste Comte brought in strong arguments in support of social sciences being a science as opposed to an art, and that the society and the people should be studied scientifically (Levine, 2018). At the beginning of the millennium, countries across the globe came together and agreed to accomplish United Nations Millennium Development Goals; with education being one of it (WHO, 2018). In doing so, Kenya spearheaded its own formula of attaining these goals, through the introduction of free primary education (FPE), which had a high affinity for increased accessibility to learning; and continuous increase in the number of public universities (Abuya, Admassu \& Ngware, 2015). This was further followed by the establishment of the vision 2030, whose success is majorly pegged on skilled human labour, with innovation, research, and technology as its key pillars (Kochore, 2016).

For those universities providing social science courses, they help in molding experts that help in carrying out research and provide professional citizen services to the populace; and help formulate policies that govern the societies. Unfortunately, there has been the discourse poking holes on the existing university curriculum as being a mismatch from the employers' expectations (Oduor, 2017). In essence, graduands are equipped with irrelevant skills and graduate with lack of relevant competencies, knowledge, and skills (Oduor, 2017). For instance, you might have an engineer who is good with theoretical information, but when it comes to practicality, they are troubled. This then raises a fundamental question: how is the training in these universities carried out?

Kenyan universities, more so, the public ones are faced with the bottleneck of increased student numbers that have overstretched the available resources, and lectures to be precise (Cambon, 2019). This quantitative work overload on the lecturers has demoralized them, given they are also not properly remunerated, and their terms of employment are not implemented to the latter (Ouma, 2016). This has been demonstrated through several strikes pitting the lecturers demand for better pay and the institutions honour of the signed collective bargaining agreements (Mwangi, 2018). The worst of all these strikes was in 1994 that lasted for a period of almost a year (VOA, 2009). The increased number of students has seen lecturers end up teaching students through dictating notes to them, or through giving out printed notes that are commonly referred to as 'handouts' (Mwangi, 2018). In this case, the university level of academia is deduced to a secondary level of learning considering that it is considered as a high level of professional training. In essence, the student should do vigorous research in the library, write their own notes, critique the works they read and come up with useful and insightful papers or proposals (Mwangi, 2018). In 
addition, dictation of notes or reading handouts enables students to inculcate the culture of memorization for academic survival; and not being resourceful to the society (Kwarteng \& Ofosu, 2018).

In relation to the low salaries that the lecturers get, they have developed a strategy for economic survival where due to the increased number of satellite campuses, they tip toe and teach from one campus to the other (Winkler, 1997; Ouma, 2016). This thus limits their ability to pursue to pursue research, publish scientific papers and even mentor the students (Winkler, 1997; Ouma, 2016). This status quo thus limits the ability for these lecturers to conduct practicals with students pursuing technical courses such as information communication technology (ICT), engineering, or taking them for fieldwork such as sociology, psychology, community development and so forth, to see and learn how programs are managed, how funding is sought, what challenges they face, how they relate with other stakeholders et cetera. This position is supported by Kara, Tanui and Kalai (2016) research titled, Quality of academic resources and students' satisfaction in public universities in Kenya that found 64 per cent of students in the selected universities noted inadequate laboratory facilities, which was a disservice to students pursuing courses requiring the facilities.

The training that is given in our universities by the lecturers needs to be given critical considerations for the wellbeing of our future professionals; as lecturers qualifications is not the only parameter to be looked at for universities to attain their goals (Ouma, 2016). For instance, during every semester, students are given assessment forms to give a score card of the lecturers and course at large, though the outcome is not strictly adhered to (McCowan, 2017). The overall process also lacks credibility, as students might be intimidated to give high scores to lecturers and courses, they feel they want to pass, reduce cases of missing marks or repeat of the course in another semester. In relation to this challenge, Kwarteng and Ofosu (2018) contends that:

In the African context, quality university education invariably focuses on student admission standards, lecturers' academic qualifications, rigorous examination protocols, degree programme requirements, course content and availability of laboratory and classroom facilities. Little or no attention is paid to pedagogy, which is left entirely to the discretion of lecturers.

This method of giving out handouts is a recipe for poor scholarship habits such as: absenteeism of students, who seek for printed notes during the lectures for the purpose of passing examinations (Mwangi, 2018). Through having vigorous practical and field work excursions, it is easier to monitor the progress of students in terms of their understanding of the theory taught in class and the real challenges on the ground. This thus raises a fundamental question: How often do the universities review their curriculum to meet the employers and societal needs? Are lecturers taken for more workshops and trainings to sharpen their pedagogical skills and exchange ideas with their colleagues both locally and internationally?

This menace of producing less qualified graduates and unequipped learning institutions has seen several university satellite campuses closed. Examples include Uzima College which is a constituent college of Catholic University of Eastern Africa (CUEA), and Masinde Muliro University of Science and Technology (MMUST) campuses in Budalangi, Busia County (Mwangi, 2018). Thus far, it is imperative to do a thorough soul search as a country and ask ourselves, why are there so many unresolved challenges 
within the society ranging from socio-economic, political, technological, social cohesion; and yet every year, universities churn out almost 100,000 graduates to the job market? On the international front, our universities are not ranked among the top best universities according to reputable ranking firms such as webometrics, Forbes, QS World University Rankings et cetera. For instance, in the year 2020, webometrics rankings of universities globally that was based on education and research publications, saw the University of Nairobi that was ranked the best university in Kenya sit at position 956. In Africa, this ranking placed 11 universities at top 1000 universities; implying that African universities have a huge gap to fill to catch up with their counterparts in United States and Europe. This therefore calls for their proper financing, proper training, and regulation of student enrollments to optimum for these grievances to be a history of the past (Munene, 2016a).

\section{Hiring of Human Resource in the Universities}

The word university comes from the Latin word universitas which means a family of scholars bonded by education (Wikipedia). In this sense, therefore, the university is epitomized to be a place where people from different regions across the world, from different creed, socio-economic status, religion, and ethnicity come together, in the quest of attaining higher education. The same is also envisioned in the academic staff and management of universities as they also come from diverse backgrounds with the aim of embracing different talents of individuals. For instance, in the United States and Europe, there has been several Africans in their academic staffs, involved in teaching African culture, history and literature; that the natives are interested in (Firsing, 2016). In the same spirit of universality, Kenyan universities have also honoured the contribution of different personalities across the world, by naming the infrastructures after them. For instance, the University of Nairobi has the Gandhi Wing B that houses lecturers offices and classes, that is named after the former India Prime Minister Mahatma Gandhi; and Moi University that has Margaret Thatcher Library that is named after the former British Prime Minister, Margaret Thatcher who was referred to as 'iron lady' for her intellect, prowess, and leadership.

Several universities have also taken the advantage of globalization, through signing pacts with other universities for collaboration purposes. This has in turn saw increased exchange programmes of both the students and lecturers (Odon, 2015). In addition, there has also been the aspect of having foreign guest lecturers for the purposes of teaching and conducting external evaluations, for the universities to work on the same platform. It is through this exchange programs that gave rise to increased scholarships for the needy students; more so, in Africa, a program that was spearheaded by W.E.B Dubois and his colleagues in the 20th century (Kendhammer, 2007). In Kenya, Tom Mboya utilized the platform of providing scholarships to Africans to learn in the United States and Canada; and beneficiaries such as Barrack Obama Senior, newspaper columnist Philip Ochieng, Wangari Maathai among others benefitted from this program and were the first crop of Kenyans to earn a Doctor of Philosophy (Ph.D.) degrees in their respective fields (Nkosi, 2015). The critical component to success of the university institutions lies in their hiring process. In essence, it strictly adheres to the required credentials, skills, and qualifications, it will bring on board persons that will steer the universities to higher scales, while to the contrary, it will result to their stunted progress (Munene, 2016b). In most of our Kenyan universities, this is a process that is marked with 'who knows who', and the terms of contract, remuneration and promotions are pegged on someone's loyalty to the management; and not based on competency (Alemiga \& Kibukamukose, 2019). As a country, 
therefore, we need to understand where the rains started beating us, to the current slow but steady decline of our university education?

From the onset, our departure point took the wrong footing when the mandate of the chancellor was given to the head of state (Cambon, 2019). This means that he was the one to appoint the university vice chancellors and influenced the subsequent appointments of university managements. This in a nutshell brought about the aspect of politicization of university employment, as he only appointed his cronies to the lucrative positions (Cambon, 2019). Universities are institutions that should be established with a solid need. This may touch on infrastructure planning and development, medicine advancement and research, technology advancements and so forth. In this regard, the institutions should be led by technocrats that are guided by their academic expertise and skills in serving the students (Munene, 2016b).

Politicization in the university saw local leaders embrace the present regime, and always sought for what they termed as 'our' university in their area of jurisdiction (Munene, 2016b). This thus beats the logic of establishing such kind of universities, as they up duplicating what other institutions are doing. In essence, objectivity of such institutions is lost to the perception of feeling considered by the head of state (Ouma, 2016; Munene, 2016b). Once the battle of bringing the university in each region has materialized, this is followed by the ethnic quest of jostling for the available jobs (Munene, 2016b). In a good system of hiring staffs on board, it is guided by competence, skills, and expertise of an individual towards a particular job. Unfortunately, in these regional universities, the area ethnic group sweeps almost all the positions, from management, teaching and subordinate staffs, with disregard to an individual's competence (Ouma, 2016). This position is well put by Munene (2016b) who propounds that:

The nexus between ethnicity and university development has compromised governance, too. Chancellors, council members, vice chancellors and other senior administrators are often selected from an institution's immediate surrounds. This means that appointments are happening along ethnic lines sometimes with no consideration of merit.

This hiring process thus implies that someone must be fooling the other. In this case, the interviewees, and the university councils, with the later having their own preferred choices. It is also retrogressive for more employees from the same ethnic group to work in the same institution, as they think the same, and cannot critique the unfair practices for the betterment of the institutions (Patrick \& Kumar, 2012). An example is the case of Professor Laban Ayiro who was appointed as the Acting Vice Chancellor of Moi University in 2016 by Cabinet Secretary of Education Dr. Fred Matiangi, which was followed by unrest led by local politicians, staffs from the area ethnic groups and locals (Opiyo, 2016). This was the highest form of humiliation and marginalization towards an established scholar, with the capability of leading the institution; and staffs from different ethnic groups as it could have triggered the feeling of belonging in the wrong place (Mukinda, 2016). This kind of acts also brings about nepotism and corruption, all of which are covered up due to lack of whistle blowers (Opiyo, 2016).

\section{So What is the Way Forward?}

The main mandate of the Commission of University Education (CUE) is to certify that each accredited university, offers quality education of courses to students, has qualified lectures, adequate infrastructure 
such as libraries, lecture rooms and hostels (Opata, 2016). Unfortunately, the CUE has demonstrated that our universities are a sinking ship, that must be rescued (Ouma, 2016; ICEF Monitor, 2017). In the last two decades, the populace focus has been on the attainment of undergraduate degrees, that has seen the numbers rise, diluting the quality of the attained degrees (Cambon, 2019). If no effort is put in place, and with employers starting to consider post graduate degrees, this will attract more students, that in the next half a century, we will have no quality master and Doctor of Philosophy (Ph.D.) degrees. For instance, in a study that was conducted by the Inter-University Council of East Africa in 2014, it found that close to 50 percent of graduates were completely grey and lacked the skills and competencies to execute duties in their area of training (McCowan, 2018). This paper thus offers the following probable remedies:

a. Consolidating university programmes

The proposal by the Ministry of Education (MoE) to the universities to consolidate their programmes into specialized handful of them is the way to go (Nganga, 2019). This will reduce the duplication of courses by the universities; and will help the public know what each university stands for, and majors in its training (Nganga, 2019). For instance, Kenyatta University was known for education courses; Jomo Kenyatta University of Science and Technology (JKUAT) for information and technology courses; Egerton University for agriculture and so forth. This specialization will allow the lecturers to give the required expertise and help model their students to competent professionals (Nganga, 2019). In essence, therefore, the quantitative increase in the university institutions should be directly congruent to the qualitative increase of graduates at the end of their degree programmes (Kagondu \& Marwa, 2017). In addition, the CUE should be steadfast in cracking down universities that do not conform to the stipulated guidelines, to ensure that a lot of financial investments by parents and sponsors does not go to waste; and the time of the students wasted in the name of seeking for knowledge (Opata, 2016).

The university curriculum ought to be addressed (Oduor, 2017). In the ancient times, two philosophers, Heraclitus a proponent of change, and Parmenides a proponent of permanence differed in principle on what is real between change and permanence (Oden, 2019). Heraclitus believed that change was a reality while Parmenides thought it was impossible. Aristotle solved the puzzle by agreeing with both Parmenides and Heraclitus, that change, and permanence are real, though the latter had to manifest a transition from one point to another (Oden, 2019). In our case, the university curriculum should not hold the thought of permanence, and thus ought to dynamic. It should undergo change through being regularly updated to remain relevant in the constantly changing world. For instance, during the covid-19 pandemic in 2020, it has exposed their inefficiencies such as lack of technology in our universities that has left them closed to regulate the spread of the virus (Ngalomba, 2020). They should explore other teaching methods other than the face-to-face basis, to the use of zoom, tele conferencing for the post graduate programmes, to ensure learning is not put to a halt. This calls for the investment of adequate computers and stable internet for the stability of the programme.

b. The hiring of university academic staffs and management 
The acquisition of new staffs on board is a fundamental process in an institution; as it brings new talent, diversity and reduces workload, bringing the best out of the team (Patrick \& Kumar, 2012). This has been the weak link in most of the recent established universities as they have opted to hire more employees from those regions (Munene, 2016b). It is thus imperative that the composition of university councils be scrutinized, and ensure it reflects the face of Kenya, that is, persons constituting them come from different ethnic groups in Kenya. In addition, they should also be composed from the representative from public institutions such as the public service commission (PSC), MoE, to ensure that whenever the hiring process is conducted, more so, in the public universities, they are fair and exhibit regional balance. This will help curtail the dubious practice that might be instigated by university councils in selecting their preferred candidates and put aside meritocracy, vision, and goals of their respective universities; particularly when looking for new vice chancellors (Munene, 2016b).

Upon being given the necessary support, this process of hiring is also instrumental in increasing the workforce to try and consumerate the work at hand. This has been a major teething problem affecting our universities. For instance, the status of 118 doctoral graduands from JKUAT is at stake and faces the possible wrath of being scrapped for low quality supervision of their theses, as a lecturer did more supervision of close to 16 students as opposed to three (Aineah, 2019). The agony that university students go through, more so, in the postgraduate programmes, is elucidated by Winkler (1997), who posits that:

It is hard to get a Ph.D. in Africa. Not impossible, to be sure, but difficult. University bureaucracies put up innumerable obstacles, for example, requiring students to submit dissertation proposals to committees that can take months to convene and even longer to approve the proposals.

In addition, it is also paramount that all lecturers that serve their universities in different departments, their biodata information containing their academic qualifications, work experience history and research publications be put on universities websites. This will make it easier for students, their parents, and sponsors to assess the quality of the lecturers in their children's departments and make an informed choice of whether to enroll them in that university or not.

c. Regularized enrollment of students to universities

The institutional enrollment of students, particularly in Module II programme has greatly contributed to the increased number of part time and school-based students, which have posed a strain to the available resources that are also used by full time students (Kagondu \& Marwa, 2017). There should be the introduction of special examinations for students who have passed their Kenya Certificate of Secondary Education (KCSE) before being admitted to the various courses. This is because KUCCPS has been placing students to courses against their will. This will enable students to concentrate and give their all in their preferred choices. In addition, the selection of private selfsponsored students (PSSP) should not be left to the universities alone. In essence, KUCCPS should also work in unisom with universities in selecting PSSP students in defined periods of the year based on the available facilities. This strategy will help prevent malpractices of universities admitting 
students with questionable qualifications, who will end up engaging in negative academic practices such as exchange of grades for money, sex; and further inhibit the students from inculcating the culture of being spoon fed (Kwarteng \& Ofosu, 2018; ICEF Monitor, 2017).

d. Proper funding of universities

The government should reconsider efforts towards pumping a lot of finances to the universities, as it will in the long run help in mitigating several challenges within the country (Nganga, 2020). These resources will be instrumental in adding the number of lecturers, better their salaries, and help them fund their research and scientific publications, attend conferences and seminars, and disseminate useful findings (Nganga, 2020). This will ensure that the lecturers are settled at their workstations, as the moonlighting of lecturers from one university to the other, teaching on part time basis, has severely affected the quality of their teaching and lack of time to pursue research (Winkler, 1997). The academia and politics should not be intertwined because the latter approaches issue logically, while the later does it using the populist approach (Cambon, 2019). If the national politics penetrates our universities, the level of intellect will continue to decline as the lecturers that will be brought on board will have questionable credentials (Cambon, 2019). In essence, the government should have political goodwill in ensuring there is equity in terms of distribution of funding to all public universities. For instance, when the British Prime Minister Boris Johnson contracted covid-19 virus, he was treated in one of the country's hospital (Landler, 2020). This signifies that Britain's government has invested their resources to their health facilities and professionals. In Kenya, our leaders have developed a plan B, where in such a scenario, they could have flown to Europe, United States, and India. As Mwangi (2018) connotes in relation to our local institutions:

No tangible solutions are expected soon. Just as they prefer to receive their medical care abroad because Kenyan healthcare is comatose, our senior government officials, including those in the presidency, the opposition, and the education ministry give the local education system a wide berth.

The university should also ensure proper usage of funds they receive; by eliminating cases of corruption and using the money for development purposes. They should increase the infrastructure such as lecture rooms, hostels, libraries, stock the libraries with up to date reading materials, and invest in e-libraries and strong internet to cater for the increasing number of students with the hunger of furthering their studies (Winkler, 1997). This will help in curbing the unendless bickering and unrest of students due to the limited facilities in their respective institutions (Winkler, 1997). Upgrade of university libraries will also ensure that there is proper scholarship of both lecturers and students, and new knowledge is produced for the betterment of the society. Student numbers have also been on the rise on seeking for scholarships and education in the universities abroad (Njeri, 2019). Unfortunately, due to the high cost of the initiative, that is, getting admission fee, passport, visas, air ticket, accommodation and sustaining of oneself, it has been left to the preserve of the rich (Njeri, 2019). In this case, therefore, if as a country we cannot protect our own universities, then the margin between the rich and the poor will continue to widen, as the latter will continue accessing quality education abroad and get lucrative positions in employment, as the later upon graduation will be granted low cadre jobs (Njeri, 2019). 
The government should further invest in the technical, vocational and education training institutions (TVET), to realize its vision 2030 of being an industrialized nation (Wesangula, 2019). This has been exhibited by students with grades A in their KCSE examinations of 2019 opting to join TVETs as opposed to the universities (Onyango, 2020). Lastly, this funding should also cater for proper monitoring and evaluation of university programmes. In essence, most of them have internal evaluation mechanisms, which is not effective as they tend to cover up on their inadequacies. It is thus imperative to encourage external evaluation of its operations to raise its credibility levels. This entails encouraging guest professors or reputable firms either local or international to review courses, assess the quality of examinations given, the projects and theses submitted by students and financial usage.

e. Enhancing university close ties with relevant stakeholders

In the past two decades, universities have been signing collaboration pacts with other universities abroad. The same efforts should be driven to enhancing increasing ties and collaborations with other stakeholders such as industries, public service, and nongovernmental institutions, as they are the biggest employers in the country, and can further offer placement of students for their attachment and internship programs (Sawahel, 2018). Through this initiative, universities should strive to ensure that their graduates do not leave the institutions before placing them for attachments and assessing their performances. This attachment and internship programme will be pivotal to a student for the following reasons:

- It will help them understand and appreciate the organizations organograms, the mandate of different cadres, flow of information, flow of authority, the challenges experienced in organizations and how they are dealt with. They will further learn how interpersonal relations is exercised within an organization to achieve the organizations goals and objectives.

- It helps students to interrelate and put into practice what they learnt in class in their respective organizations. For instance, if it is the aspect of research, students will be engaged in both qualitative and quantitative research, test different theories and hypothesis, interact with the research subject in the field, and learn how to analyze and interpret research findings.

- It also enables students to establish networks that are important for their professional growth. For instance, some of the organizations might end up being the professional working stations for the students after their graduation. In the same vein, the organizations supervisors will be vital in identifying the strengths and weaknesses of the students and help mold them for the better.

- The students will also come to appreciate the collaborations that exist between different organizations for their sustainability of the projects. They will learn how organizations proposals are written, and how to engage potential sponsors; learn the different phases of the programmes, and how they are monitored.

For masters and Ph.D. students, whose curriculum ensures they have a deeper understanding of the course, they should be allowed to perfect their teaching skills, mostly, with the certificate and diploma programmes. As a country, we are grappling with increasing cases of unemployment among the graduates, which does not augur well economically (Kamande, 2019). For instance, in 2019, one 
of the media houses aired a case of a university graduate who had obtained a first-class honours degree but had tarmacked for employment without success upon graduation in 2017 (Muriuki, 2019). The story led to the student receiving more offers than he could imagine. This thus demonstrates that there exists a void between the employers and graduates, as the latter is not visible to the latter (Muriuki, 2019). There should be the establishment of a national and universities database of all graduands with their complete resumes, where all employers can access them, and utilize their knowledge and expertise. The database for individual alma mater is also essential for employers that prefer to hire graduates from a particular university.

\section{Conclusion}

At the time of independence, Kenya was at the same level with countries such as Malaysia and Singapore; but to date, there is a wider disparity between the countries, with the later having a tremendous growth. This has demonstrated through their support in their education sector, and more so, the universities. University education in the country is seen as the only array of hope to having a brighter future and attaining upward social mobility. This has been exhibited by huge investments that parents from different social economic status, sponsors and well-wishers go through to change lives. This paper attempted to answer the questions such as: one, the impact of the teaching methodologies on the quality of graduates produced. This research review holds that large classes, spoon feeding students with lecture notes or handouts ends up producing passive and non-innovative graduands that struggle to pursue research and have a deep reading culture. Two, the correlation between the university curriculum and employers' requirements. This research review holds that the continued increase in unemployment among university graduands has been catalyzed by a rigid curriculum that is not updated based on the current employers' requirements. Three, the impact of increased student enrollments to the available institution's infrastructure and academic labour force. This research review holds that the double intake of both the regular and part time students in these institutions; overstretches the available infrastructure; degrading the quality of education delivered. It is based on these foregoing that this review concludes that, it is imperative for the following considerations to be made: First, it is critical for the concerned stakeholders to review the laws to ensure CUE is given more powers and funding to tame down the sporadic establishment of universities. Secondly, pre university training should be re-introduced to all students before commencing their university training. This will enable students to have life skills training that will enable them to venture into other endeavors such as entrepreneurship; in the event white collar jobs do not come by. Thirdly, as a nation, we need to rethink about how the culture of ethnicity can be dealt with. The penetration of this menace to our higher learning institutions is the worst ever thing that denies qualified professors, who later are absorbed by other universities abroad. Finally, universities should focus on guaranteeing their students internships before graduating; through establishing collaborations with organizations and companies; to help sharpen their skills and competencies.

\section{References}

Abuya, B. A., Admassu, K., \& Ngware, M. (2015). Free primary education and implementation in Kenya: The role of primary school teachers in addressing the policy gap. Sage Journals. https://doi.org/10.1177/2158244015571488. 
Adams, N. E. (2015). Bloom's taxonomy of cognitive learning objectives. Journal of the Medical Library Association, 103(3), 152-153.

Aineah, A. (2019). 'Fake phd' storm leaves graduands frustrated after social media outburst. Standard Media Group.

Alemiga, J., \& Kibukamukose, M. (2019). Determinants of the quality of academic staff in the process of teaching and learning in private universities in Uganda. African Online Scientific Information (AOSIS), 7(1).

Athanassiou, N., McNett, J. M., \& Harvey, C. (2003). Critical Thinking in the management classroom: Bloom's Taxonomy as a learning tool. Journal of Management Education. https://doi.org/10.1177/1052562903252515.

Cambon, G. (2019). Higher education in Kenya is overrated? https://geradcambon.net

Chitere, P. N (1994). Community development: Its conceptions and practice with emphasis on Africa. Gideon S. Were Press.

Daily Monitor (Sunday November 6, 2016). Museveni concerned about quality of university Education. Dewey, J. (2018). Philosophy of Education. In: Stanford Encyclopedia of Philosophy. https://plato.stanford.edu/entries/dewey

Dong, F. M. (2014). Teaching learning strategies: Connections to Bloom's Taxonomy. Journal of Food Science Education, 13(4).

Eshiwani, G. S. (1993). Education in Kenya since independence. Nairobi, Kenya: East Africa Educational Publishers.

Firsing, S. (2016). How severe is Africa's brain drain?

Gottesman, I. (2013). Socialist Revolution: Samuel Bowles, Herbert Gintis, and the emergence of Marxist thought in the field of education. A Journal of the American Educational Studies Association, 4991), 5-31. https://doi.org/10.1080/00131946.2012.730588.

Heick, T. (2018). What is Bloom's Taxonomy? A definition for teachers https://www.webometricks.info/en/africa/kenya\%20

https://en.m.wikipedia.org/wiki/university ICEF Monitor (2017). Kenya cracks down in sweeping review of higher education quality.

Kagondu, R., \& Marwa, S. M (2017). Quality issues in Kenya's higher education institutions. Council for the Research in Africa. JHEA/RESA, 15(1), 23-42.

Kamande, P. (2019). The reality of Kenyan youth: Young, educated, ambitious and jobless. Daily Nation Group.

Kara, A. M., Tanui, E. K., \& Kalai, J. M. (2016). Quality of academic resources and students' satisfaction in public universities in Kenya. International Journal of Learning, Teaching and Educational Research, 15(10), 130-146.

Kendhammer, B. (2007). DuBois the Pan-Africanist and the development of African Nationalism. Journal of Ethnic and Racial Studies, 30(1), 51-71. https://doi.org/10.1080/01419870601006538

Knopp, S. (2010). What do schools produce? International Socialist Review.

Kochore, H. H. (2016). The road to Kenya? Visions, expectations and anxieties around new infrastructure development in Northern Kenya. Journal of Eastern African Studies, 10(3), 494510. https://doi.org/10.1080.17531055.2016.1266198

Köksal, D. \& Ulum, Ö. G. (2018). Language assessment through Bloom's Taxonomy. Journal of Language and Linguistics Studies, 14(2).

Kwarteng, E. F., \& Ofosu, S. K. (2018). Improving the quality of university education in Africa. University World News.

Landler, M. (2020). Boris Johnson leaves U.K Hospital after coronavirus treatment. The New York Times. 
Levine, D. (2018). Auguste Comte and positivism: The essential writings. Contemporary Sociology. A Journal of Reviews. https://doi.org/10.1177/0094306118805421C

Leys, C. (1979). Development strategy in Kenya since 1971. Canadian Journal of African Studies, 13(1/2), 295+297-320.

McCowan, T. (2017). Quality of higher education in Kenya: Addressing the conundrum

Mgaiwa, S. J. (2018). The paradox of financing public higher education in Tanzania and the fate of quality education: The experience of selected universities. Sage Journals. https://doi.org/10.1177/2158244018771729

Mukinda, F. (2016). Governor questioned about remarks on Moi University appointment. Daily Nation Group.

Munene, I. (2016a). Kenya's Universities are in the grip of a quality crisis.

Munene, I. (2016b). How the rise in ethnic tensions at Kenya's Universities is hurting the economy. The Conversation.

Mungai, A. (Saturday, December 21, 2019). Why top students want to study, work abroad. The Standard Media Group.

Muriuki, B. (2019). Kevin Ochieng Obede: Jobs galore for top unemployed graduate forced to live in Nairobi streets. Citizen Digital News.

Mwangi, E. (Saturday, $10^{\text {th }}, 2018$ ). How our university education system went terribly wrong. Daily Nation Group.

Nakweya, G. (2018). 76-day-long lecturer strike ends but for how long? University World News

Ngalomba, S. (2020). E-Learning-Time for a paradigm shift. University World News

Nganga, G. (2020). Government cuts universities budget by 26\%. University World News

Nganga, G. (2019). Universities on collision course with government over reforms. University World News

Njeri, J. T. (2019). Declining quality of education in Kenya drives students oversees. University World News

Nkosi, M. (2015). The airlift education scholarship that changed the world. BBC News.

Oden, C. (2019). Notion of change and permanence in Aristotle

Odhiambo, G. (2016). Higher education in Kenya: an assessment of current responses to the imperative of widening access. Journal of Higher Education Policy and Management, 3892), 196-211. https://doi.org/10.1080/136008x.2016.1150551

Odon, A. (2015). International partnerships can be powerful tools for Africa's Universities. The Conversation

Oduor, A. (Thursday $2^{\text {nd }}, 2017$ ). Report: Quality of Kenyan graduates from public universities wanting. The Standard Media Group.

Onyango, P. (2020). KCSE stars shun universities for Diploma courses. The Standard Media Group.

Opata, F. (2016). Commission for University education is to blame. The Standard Media Group.

Opiyo, D. (2016). Why Moi University is an institution on its knees. Nation Media Group

Ouma, C. (2016). Quality of education in varsities and colleges needs urgent review. Nation Media Group.

Ouma, W. (Thursday $21^{\text {st }}$, 2016). CUE revokes degrees awarded to five students by Kisii University. Nation Media Group

Ouma, W. (Thursday $1^{\text {st }}$, 2018). CUE shuts down campuses in crackdown. Nation Media Group

Patrick, H. A. \& Kumar, V. R. (2012). Managing workplace diversity: Issues and challenges. Sage Journals. https://doi.org/10.1177/2158244012444615

Pavlis, D. \& Gkiosos, J. (2017). John Dewey, From Philosophy of Pragmatism to progressive education. Journal of Arts and Humanities, 06(09), 23-30. https://doi.org/10.18533/journal.v6i9.1257

Prus, R. (2011). Examining community life “in the making”: Emile Durkheim's Moral Education. Moral Education. The American Sociologist, 42, 56-111. 
Rono, J. K. (2002). The impact of the structural adjustment programmes on Kenyan society. Journal of Social development in Africa, 17(1), 81-98.

Sawahel, W. (2018). The challenges of growing Ph.D. graduate numbers. University World News

Swartz, D. L. (2003). From correspondence to contradiction and change: Schooling in Capitalist America Revisited. Sociological Forum, 18, 167-186. https://doi.org/10.1023/A:1022663030618

VOA (2009). Kenyan University lecturers strike for improved working conditions. Voice of America News.

Wesangula, D. (2019). TVET institutions get funding from CICan to improve sectors competitiveness. The Standard Media Group.

WHO (2018). Millennium Development Goals (MDGs). https://www.who.int/news-room/factSheets/detail/millennium-development-goals-(mdgs).

Winkler, A. M. (1997). How can we help African Universities? The Chronicle of Higher Education. Zeleza, T. (1991). Economic Policy and Performance in Kenya since independence. Trans African Journal of History, 20, 35-76. 